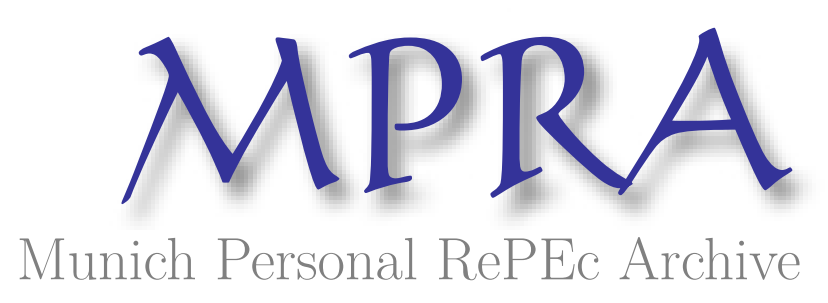

\title{
The Political Economy of Environmental Justice
}

Banzhaf, H. Spencer

Stanford University Press

November 2011

Online at https://mpra.ub.uni-muenchen.de/101191/

MPRA Paper No. 101191, posted 18 Jun 2020 08:40 UTC 


\title{
The Political Economy of Environmental Justice
}

\author{
H. Spencer Banzhaf \\ Forthcoming from Stanford University Press, 2012
}

\section{Chapter 1: Introduction}

\subsection{Introduction}

Since the landmark studies by the US GAO (1983) and the United Church of Christ (1987), the environmental justice literature has consistently shown that poor and minority households systematically live in more polluted neighborhoods. This correlation appears to be quite robust to the type of pollution considered: for example, the poor live closer to hazardous waste facilities, landfills, and other locally undesirable land uses (LULUs); they live closer to large air polluters; and they live in communities with higher concentrations of air pollutants. ${ }^{1}$ The correlation is also robust to the statistical methods employed by researchers. ${ }^{2}$ In short, the correlation qualifies as a "stylized fact" as much as anything in social science.

This finding of a disproportionate environmental burden borne by the poor and people of color has led to the introduction of several "environmental justice acts" in Congress (though none have passed) and to President Clinton's Executive Order 12898. Still in force, the order requires nondiscrimination in federal environmental programs and focuses federal resources, such as EPA's brownfield program, on low-income and minority communities. More recently, the EPA has launched a number of initiatives to incorporate environmental justice considerations into its rule making.

In addition to such top-down initiatives, the environmental justice findings have fed grassroots activist movements. Sometimes with help from national leaders of the environmental justice movement, local stakeholders have sought more involvement in permitting polluting 
facilities and in making other environmental plans. ${ }^{3}$ They also have filed lawsuits against governments for discriminatory environmental enforcement and against polluters for environmental nuisances. For example, in one prominent case, local activists forced California's Southeast Air Quality Management District to settle a suit over the geographic distribution of trades under its RECLAIM pollution trading program. ${ }^{4}$

Evaluating claims of discrimination and injustice requires an understanding of the social causes lying behind the correlation between pollution and demographics. So does evaluating the efficacy of any policy remedies. Economic models can provide important insights into these issues. These include economic models of discrimination, of local public goods and real estate markets, of firms' profit maximization, and of political organization and lobbying. Generally speaking, these models have tended to "push back" the locus of injustice from firms' individual decisions, such as where to locate and how to operate, to the more fundamental issue of the distribution of income and wealth and the ways in which markets allocate goods-including environmental amenities - to households. This point has been made well both by critics and participants in the environmental justice movement, and has been discussed fruitfully by such authors as Vicki Been (1993, 1994), Lynn Blais (1996), Sheila Foster (1998), Laura Pulido (2000) and others.

Despite the importance of the question, we do not really understand which socio-economic forces lie behind the observed correlations. Moreover, the full implication of these various economic models for the distributional impacts of potential policy remedies for environmental injustice has not been well understood either. Yet if the ultimate social goal is actually to improve the welfare of disadvantaged groups, as well as to describe social processes, understanding the distributional effects of environmental policies is crucial. These distributional effects will in 
turn depend on the social process generating the observed pattern in the distribution of pollution. Consequently, the social forces driving the poor's exposure to pollution represent a critical lacuna in our understanding.

\subsection{The Lone Mountain Forum}

For this reason, we felt it was time to re-visit environmental justice questions, with a concentrated effort to flesh out the economic and social dynamics lying behind the observed correlation between pollution and demographics. The opportunity to make that effort came with a Lone Mountain Forum, organized by the Property and Environment Research Center (PERC). The forum was made possible with generous support from the Earhart Foundation.

The authors of the papers included in this volume gathered together in Big Sky, MT, in October 2008. The authors were all economists, but our group also contained a mix of additional

economists and legal scholars who joined us in the dialogue. ${ }^{5}$ Additionally, the group included a mix of scholars long engaged in the environmental justice literature as well as others who were new to it, who brought fresh perspectives.

One thing we did not try to do was to revisit the question of whether or not there is a correlation between pollution and the presence of poor or minority households. Granting the presence of at least a simple correlation, we came rather to discuss questions about the economic forces lying behind it, seeking to gain insights from both theoretical models and empirical analyses. We also wanted to explore the implications of these insights for public policy.

The papers in this volume are the fruits of that meeting. While they all come from the perspective of economists, our hope is that they will of use to all participants in environmental justice conversations, including legal scholars, sociologists, geographers, philosophers, and historians, whether in academia, government, business, or community organizations. 
These research questions and their intended audience motivated the title of the collected volume, The Political Economy of Environmental Justice. The term "political economy" conveys the discipline of economics lying at the heart of the volume, of course, but it has numerous additional shades of meaning beyond simply "economics." It can mean the economic analysis of politics and public choice, including interest-group politics, regulation, and redistribution. It can mean simply wedding economics to public policy. And it has an older, archaic meaning growing out of its roots in moral philosophy, as the more comprehensive study of societies and states in all their economic, political, legal, and moral aspects. All of these meanings are meant to be packed into this term which serves as the volume's title.

\subsection{Economic Models of Environmental Justice}

Economists' perspective on environmental justice issues was articulated first and best by James Hamilton (1995). Hamilton identified three broad categories of explanations for environmental justice correlations: pure discrimination, economic efficiency, and political action. Promoting some of his subcategories and adding another, I will consider these in six categories.

The first category is "pure discrimination." Following the model of Becker (1957), this notion is that firms may have a differential preference for sheltering whites from pollution, or even a perverse desire to harm minorities. Essentially, firms act to achieve a set of objectives which include not only profits, but also discriminatory preferences for environmental outcomes on different demographic groups. Firms would thus make production decisions that harm minorities even if it is not in their own profit-maximizing interests, paying a price in foregone profits to indulge their discriminatory tastes. Believing firms focus solely on profits, economists tend to be skeptical of this explanation.

A second interpretation, known as "coming to the nuisance," essentially reverses the 
causality. Firms site their facilities and make other production decisions for numerous reasons, and local demographics may be a negligible factor. If they do emit pollution in any given location, for whatever reason, however, it will make that location less attractive to residents. Wealthier households in particular, with more opportunities, will move out, lowering demand for housing in the area. Consequently, local land and housing prices will fall. Poorer households may actually move in, prioritizing the low housing costs despite the disamenity of the pollution. This process was well articulated by Vicki Been in a series of influential papers (1993, 1994, 1997), as well as by Hamilton (1995) and Blais (1996). Banzhaf and Walsh (2008) and Banzhaf, Sidon, and Walsh (this volume) confirm this intuition in a formal economic model in the style of Tiebout (1956), in which households choose neighborhoods in which to live based on local amenities and costs (including property prices and tax rates).

In this way, the demographics might follow the spatial distribution of the pollution. As long as there is some pollution, pollution must have a spatial distribution, and so somebody will be nearest to it. As emphasized by Charles Tiebout himself, these models suggest that ultimately the spatial distribution of pollution is economically efficient. The term "efficient" is a linguistic minefield, which can lead to substantial misunderstanding between economics and others. To economists, it means simply that households with the highest values for a cleaner environmentthose with the highest willingness to pay, in economists' jargon— do in fact avoid it in the end. Conversely, those with the lowest willingness to pay for a cleaner environment - those least willing to sacrifice other goods like housing, food, or entertainment — are the ones living nearest the pollution.

If people's values for avoiding pollution differ because of differences in family makeup (e.g. the presence of children or the elderly), physical sensitivity to pollution (e.g. having 
asthma), or similarly formed preferences, then the allocation would seem quite sensible indeed. However, these values also proceed from people's ability to pay, based on their income. This raises additional questions about the nature of injustice, but pushes those questions back to the underlying distribution of income itself as the more fundamental issue. That is, the question turns to why particular groups or individuals are poor in the first place, and hence unable to acquire some of the good things in life - a clean environment included.

A third, and closely related, interpretation is that the geographic pattern of local environmental nuisances arises from negotiations between firms and local stakeholders, in which firms compensate communities for hosting unwanted facilities (Hamilton 1993, 1995). As Ronald Coase (1960) famously argued, such negotiations would arise when the right to pollute (or to be free of pollution) is clearly defined and when the costs of negotiation and transacting compensatory payments are low.

Coase (1960) pointed out that when property rights are well defined, they also become tradable. Specifying the right to pollute—or to be free from pollution—allows pollution too to be traded. Coase suggested, for example, that negotiations could arise over factory smoke. If factories have a right to pollute, local residents may pay them to not pollute. If local residents have a right to be free from pollution, factories might compensate them to accept some pollution. In the same way as can happen through land markets, environmental quality will again be highest near those who value it most highly, and lowest near those who are prepared — for whatever reasonto sacrifice fewer other goods to obtain it.

In this Coasian world, other things equal, firms would locate in neighborhoods that are willing to accept lower payments as compensation. Like the Tiebout model, the Coasian model implies that the spatial distribution of pollution is economically efficient, but again only 
conditional upon the existing distribution of income. The primary difference between the two models is that Coase's is a story of firms choosing a location based on its negotiations with local residents, whereas Tiebout's is a story of households choosing a location based on its existing amenities and prices.

Fourth, firms may seek out areas with weaker political resistance to their polluting activities. If local residents must use costly political action to fend off unwanted pollution, then the level of their political resistance is likely to be proportionate to their willingness to pay to avoid pollution. In this way, political wrangling can be, for all practical purposes, a special form of the pricing mechanism operating through the Coasian process, and so too the outcome might be efficient in the same way — again, conditional on the existing income distribution (Becker 1983). ${ }^{6}$ Those with the highest willingness to pay to avoid pollution invest the most in pollution-resisting activism; meanwhile, firms seek to avoid paying the political cost of trying to overcome such activism, and so avoid those communities.

However, the strength or weakness of a community's political opposition may not, in fact, be proportionate to their desire to avoid pollution. Some communities may have better access to the hall of power than others. Others may be better organized politically or, in Coasian language, may face lower transactions costs of coming together to negotiate with (or oppose) polluting firms. Hamilton $(1993,1995)$, for example, found that communities with lower voter turnout were more likely to see local firms expand their processing of hazardous wastes (see also Brooks and Sethi 1997 and Arora and Cason 1999). From this perspective, environmental justice activists who provide legal advice and facilitate local capacity building in poor neighborhoods are achieving two ends: they are serving the poor while helping these social processes to function more efficiently, lowering Coasian transactions costs. 
A fifth interpretation is that firms, while not reacting so much to local demographics per se, are attracted to other factors which happen to be spatially correlated with the demographic composition of neighborhoods. Examples of such factors might include low wages, low land prices, access to transportation corridors, and proximity to suppliers or to other similar firms (because of so-called "agglomeration economies"). Wolverton (2009 and this volume) finds that such factors do appear to be one of the main drivers behind firms' location decisions. Some of these factors, like low wages, might in fact be demographic characteristics. Other factors might be correlated with demographics indirectly through Tiebout-like processes. For example, nearby transportation corridors may be an attractive amenity to firms but a disamenity to households, one that drives away the richer residents. Or, the age of a community's housing stock might well be tied historically to the development of nearby manufacturing, and it may be the lifecycle of the housing stock that drives the observed correlations. Research by Rosenthal (2008) and Brueckner and Rosenthal (2009) shows that a community's population tends to grow poorer over time along with the age of the housing stock, until the community reaches a time of redevelopment and renewal. Further exploration of this so-called "filtering" model in the environmental justice context would be fruitful.

A sixth and final interpretation focuses attention not so much on firms as on government, and its failure to enforce environmental standards and regulations equitably. Governments might, for example, enforce such provisions more rigorously in areas with higher levels of political support for the current administration. But they need not be intentionally discriminatory for such outcomes to arise. Government enforcement agencies may find it easier or even more efficient to react to complaints from local citizens. But as with the "squeaky wheel that gets the grease," those agencies would be more likely to respond to better organized, better connected, and 
otherwise more politically powerful citizens (see McCubbins and Schwartz 1984, Hamilton and Viscusi 1999). If environmental justice communities are more poorly organized or politically connected, this dynamic would give rise to the observed environmental justice correlations. (If so, this might also be a further reason why firms would be attracted to areas with less political power.)

\subsection{Why Why Matters}

No doubt others would be able to offer additional explanations, but these are the ones most likely to occur to most economists. Even the very act of listing them out can help overcome a common misunderstand between economists and others about the idea of "environmental justice" or "environmental racism." When an economist hears these terms, he typically thinks in terms of the first model described above, the story of pure discrimination, in which firms sacrifice profits in order to steer pollution toward less-valued groups. Interpreting "discrimination" or "injustice" through the lens of this particular model, economists and many social scientists have tended to subject environmental justice correlations to various controls, through multivariate regression for example. If the correlation between pollution and poor and/or minority populations disappears when controlling for other factors, such as education, land values, or voting turnout, then economists often conclude that there is no environmental justice concern. Indeed, they too often conclude that environmental justice advocates and researchers from other disciplines are simply naïve.

In fact, if we economists would spend a little more time in the environmental justice literature, we would realize that very few people have ever made the suggestion that firms' tastes for something like "pure discrimination" are responsible for the observed correlations. Most are well aware of the socioeconomic processes involved. Indeed, many scholars, like Bullard (1990), Foster (1998) and Pulido (2000) for instance, have articulated nuanced conceptual frameworks for 
interpreting environmental justice questions, frameworks which exhibit a grasp of the economic issues that might surprise some economists.

From the point of view of many of these alternative frameworks, the fact that market and/or political forces lead to the observed correlations between pollution and demographics does not render the question of an "injustice" moot. Indeed, consider the US EPA's definition of environmental justice:

Environmental Justice is the fair treatment and meaningful involvement of all people regardless of race, color, national origin, or income with respect to the development, implementation, and enforcement of environmental laws, regulations, and policies. EPA has this goal for all communities and persons across this Nation. It will be achieved when everyone enjoys the same degree of protection from environmental and health hazards and equal access to the decision-making process to have a healthy environment in which to live, learn, and work. (US EPA 2010)

Bryant (1995) defines it this way:

[Environmental justice] refers to those cultural norms and values, rules, regulations, behaviors, policies, and decisions to support sustainable communities, where people can interact with confidence that their environment is safe, nurturing and productive. Environmental justice is served when people can realize their highest potential, without experiencing the "isms." Environmental justice is supported by decent paying and safe jobs; quality schools and recreation; decent housing and adequate health care; democratic decision-making and personal empowerment; and communities free of violence, drugs, and poverty. These are communities where both cultural and biological diversity are respected and highly revered and where distributive justice prevails. (p. 6)

Of the two, Bryant's is clearly the more holistic, encompassing a wide range of issues only indirectly connected to the natural environment. But the key point is that both definitions encompass notions of procedural justice as well as distributive justice, while neither focuses on the question of the intent of polluters. ${ }^{7}$

Beyond clarifying the vocabulary of "discrimination," understanding which of these explanations are the most significant is important for three additional reasons. First, it colors the interpretation of the injustice in the distribution of pollution. Second, it has implications for the 
efficacy of policies designed to reverse environmental justice correlations. And third, it has implications for the actual welfare effects on the poor of cleaning up their neighborhoods.

If the correlation between pollution and minority and poor populations results from intentional discrimination by government agencies, it would violate the equal protection clause of the Constitution and possibly Title VI of the Civil Rights Act (which prevents discrimination by agencies receiving federal funds). ${ }^{8}$ Even if there was no discriminatory intent, there would still be a question of the justice in the agencies' procedures as well as distributive justice.

If the observed correlations are a consequence of "coming to the nuisance" and similar socio-economic processes mediated through real estate markets and housing decisions, however, then the correlation between pollution and demographics appears not so much a cause of an unequal distribution as a result. In this case, there is still a question of distributive injustice, but the locus of that injustice lies in the underlying distribution of income rather than in the distribution of environmental quality.

The environmental justice literature, by and large, has acknowledged the potential role played by market dynamics while arguing that such processes do not undermine the normative significance of the injustice of disproportionate environmental burdens. Be that as it may, it does not follow that understanding such social processes are irrelevant. However unfair the distribution of income, markets provide an effective opportunity for individuals and groups to enhance their welfare, given their limited resources. It follows that if market-based processes (such as Tieboutian allocations mediated through real estate markets and Coasian bargaining over pollution itself) are important, then undermining the market outcomes may undermine the efforts of even the most disadvantaged groups to better themselves. Focusing on the root problem—poverty - by redistributing income is likely to be a more effective way to improve the welfare of the 
poor than improving environmental quality.

For example, a Tiebout process of "coming to the nuisance" would undermine the efficacy of any policies designed to reverse the correlation through the targeting of firm behavior. As pointed out by Been (1993), as long as some areas are more polluted than others, migration might always re-establish the correlation. Perhaps more importantly and more surprisingly, the process would have important and counter-intuitive implications for household welfare. For instance, Sieg et al. (2004) and Walsh (2007) find that targeting dirty, poor neighborhoods for clean-up with the intention of helping the local residents can be counter-productive. The reason is that residents who live in dirtier communities tend to place a high priority on low-cost housing relative to the environment, presumably because they cannot afford to sacrifice such necessities given their limited finances. In contrast, new residents who move in following a cleanup have a higher willingness to pay for environmental quality. As they move in, they bid property values up by their own higher willingness to pay. Thus, cleaning up the environment may increase housing costs for the poor by more than their willingness to pay. Moreover, as they generally rent their housing, poor residents stand to lose from these increased housing costs, while landlords reap the benefit. Sieg et al. (2004) refer to this effect as "environmental gentrification." Such perverse distributional effects are not only a concern of the academic literature: they have emerged as a top concern of grassroots movements as well, as expressed in a recent report from the National Environmental Justice Advisory Council (NEJAC 2006). This issue of environmental gentrification is discussed in more detail in Banzhaf and McCormick (this volume) and Vigdor (this volume).

\subsection{Role of Housing Discrimination}

One theme in the economic approach to environmental justice that has emerged is the importance 
of market processes in allocating pollution, as a more subtle yet more realistic process than pure discrimination in production decisions. But this begs the question, what about discrimination in those mediating markets, especially the real estate market?

The question pushes the logic back one step, but many of the principles are the same. The most overt possibility here is pure discrimination in the housing market. In this case, pure discrimination is, on the face of it, more plausible, though discriminating sellers or real estate agents must still pay a price for their discrimination in the form of foregone customers. Nevertheless, historically, pure discrimination in the housing market has taken the form of neighborhood covenants and the refusal to sell or rent to individuals of color. But there is an indirect version of discrimination here as well. A more subtle form of discrimination is the decision of individuals to live (or not live) in a neighborhood based on its demographic composition. For example, segregation will arise if whites prefer to live with other whites, as evidenced in processes such as "white flight." Importantly, the converse does not necessarily follow: the existence of segregation does not necessarily imply such indirect discrimination. It could follow, for example, from the Tiebout process and inter-racial differences in willingness to pay for public goods (Mcguire 1974).

Cutler, Glaeser, and Vigdor (1999), in their fascinating historical study of segregation in America from 1890 to 1990, found that the pattern of housing costs for blacks and whites suggests that pure discrimination marked the rise of segregation in the first two-thirds of the twentieth century, but that the more implicit form, based on individual residential choices, was more salient by $1980 .{ }^{9}$ Card, Mas, and Rothstein (2008), for example, estimate that in most cities, whites begin to flee neighborhoods when minorities comprise 5 to 20 percent of the population. These estimates are consistent with survey findings about whites' tolerance for minority 
neighbors. Blacks, on the other hand, state that they prefer a 50-50 mix of racial composition (Farley et al. 1978 and Farley and Krysan 2002).

Such housing market behavior can magnify the consequences of the Tiebout model for environmental justice. As shown by Schelling (1971, 1972), even when everybody prefers some integration, such preferences can result in a "tipping point" at which communities become quite segregated. When combined with the Tiebout model, it is not surprising that whites enjoy the high-amenity areas (see Becker and Murphy 2000, Banzhaf and Walsh 2010, Banzhaf, Sidon, and Walsh, this volume). These areas have higher land values not only because of their environmental amenities, but also because the white majority values them simply because they are more white. This white premium becomes yet another force driving minorities to more polluted communities: not only must they join white communities to obtain high levels of public goods, risking being the odd man out, they must pay extra for the privilege (Ford 1994). Consistent with these hypotheses, Depro and Timmins (this volume) find preliminary evidence that minorities face a higher opportunity cost of obtaining clean air than do whites.

\subsection{Advancing the Ball}

The papers in this volume all speak to one or more of these issues, either testing various economic theories of environmental justice correlations, working out hypotheses about their respective implications for public policy, or testing those derived hypotheses. A plurality of the papers explore various aspects of Tiebout's hypothesis that real estate markets mediate the exposure of demographic groups to pollution. Reviewing the evidence, Eleanor McCormick and I find substantial support for this mechanism (Chapter 2). We also find evidence of gentrification effects on prices. Brooks Depro and Christopher Timmins (Chapter 5) provide additional evidence of Tiebout's process in a detailed study of households' responses to ozone improvements. Whites 
appear to be more likely to move up to low-ozone neighborhoods when they move than do Blacks or Hispanics.

On the other hand, in Chapter 6, Trudy Ann Cameron, Graham Crawford, and Ian McConnaha do not find such systematic patterns in their examination of the evolving demographics around superfund sites. They point out that white males tend to view environmental risks as smaller, so minority and female-headed households may be less likely to "move to the nuisance." Moreover, they point out that observing these patterns in the data over time is complicated by the changing perceptions of risks as some contaminated sites are either cleaned up or alternatively permanently stigmatized.

Other papers exploring the issue add additional nuance to our understanding of gentrification. Jacob Vigdor (Chapter 3) points out that if environmental justice communities have many vacant houses, then the excess housing supply may be more than sufficient to absorb the increase in demand following cleanup, so investments in environmental justice communities may not trigger price increases. Similarly, Douglas Noonan (Chapter 7) points out that many projects involve redevelopment. If the increased supply from the new development balances the increased demand from the improved amenities, then there will not be any price effect. Neither author finds evidence of price appreciation in the applications they consider, cleanup of Superfund sites in the former case and a brownfield-to-greenfield project in the latter. Finally, in Chapter 4, Joshua Sidon, Randall Walsh, and I consider the case where households sort on the demographic composition of the community as well as amenities like the local environment. Such preferences reinforce the observed environmental justice correlations, but also dampen gentrification effects.

Ann Wolverton (Chapter 8) offers what may be the strongest analysis of firm locational choice in this literature. She finds that when firms site their polluting facilities, they prioritize 
factors that likely lower their operating costs, locating in areas with lower wages, with good access to transportation, and with existing activity in their industry. After controlling for these factors, the racial composition and income of communities do not appear to be a factor.

There thus seems to be substantial evidence for the second hypothesis for observed environmental justice correlations discussed above (mediation through land markets) and the fifth (profit-maximizing locational choices by firms). However, progress is not made only by verifying ideas. Eliminating hypotheses is just as useful. In Chapter 9, Ronald Shadbegian and Wayne Gray consider the sixth hypothesis, discrimination by governments. They test for variation in states' pollution enforcement activity based on local demographics, and find no connection (with the exception that liberal areas get more enforcement and conservative areas less). Similarly, in Chapter 10, Robin Jenkins and Kelly Maguire find no connection between state taxes on hazardous wastes and local demographics.

This still leaves at least two important economic theories which were not explored by the authors in this volume. One is Coase's theory of compensatory transactions for pollution. There is some evidence that Coasian processes are functioning in local pollution markets. For example, in their study of the largest solid-waste landfills in the U.S., Jenkins, Maguire, and Morgan (2004) find that about half of the landfill owners provide compensation to communities, with payments averaging about $\$ 1.5$ million in 1996, and in one case $\$ 20$ million. Forty-six percent made regular cash payments and 36 percent made miscellaneous in-kind payments, such as wells, parks, firehouses, and so forth. Thus, although not universal and although probably hampered by high transactions costs, Coase's mechanism appears to be working, at least to some extent.

The second hypotheses that the papers in this volume do not directly address is the role of 
political power and local interest groups in firms' pollution decisions. As noted previously, polluting firms may avoid communities that are better organized and have more political power, and Hamilton $(1993,1995)$ presented evidence on the importance of these factors, as measured by voter turnout. Since Hamilton's seminal work on this topic, new developments in the political economy have opened up potentially new lines of inquiry. For example, Alesina, Baqir, and Easterly (1999) have hypothesized that areas with more demographic heterogeneity will have the hardest time assembling for collective action. They find that more heterogeneous communities have lower levels of public goods. Similarly, Vigdor (2004) finds that such communities have lower response rates for the US Census, despite the fiscal advantages to a community of responding. Similar organizational problems may plague heterogeneous communities when it comes to negotiating (or opposing) polluting facilities (Videras and Bordoni 2006).

Both these areas are worthy of further exploration, as are no doubt all those discussed in this volume. If the volume succeeds as we hope, it will be in its role as a conversation starter that motivates still more exploration of those topics. 


\section{References}

Alchian, Armen, and Harold Demsetz. 1973. "The Property Rights Paradigm." Journal of Economic History 33: 16-27.

Alesina, Alberto, Reza Baqir, William Easterly. 1999. "Public Goods and Ethnic Divisions." Quarterly Journal of Economics 114: 1243-84.

Arora, Seema, and Timothy N. Cason. 1999. "Do Community Characteristics Influence Environmental Outcomes? Evidence from the Toxics Release Inventory." Southern Economic Journal 65: 691-716.

Ash, Michael, and T. Robert Fetter. 2004. "Who Lives on the Wrong Side of the Environmental Tracks? Evidence from the EPA's Risk-Screening Environmental Indicators Model." Social Sciences Quarterly 85: 441-62.

Baden, Brett M., and Don L. Coursey. 2002. "The Locality of Waste Sites within the City of Chicago: A Demographic, Social, and Economic Analysis." Resource and Energy Economics 24: 53-93.

Baden, Brett M., Douglas S. Noonan, and Rama Mohana R. Turaga. 2007. "Scales of Justice: Is there a Geographic Bias in Environmental Equity Analysis?" Journal of Environmental Planning and Management 50: 163-85.

Banzhaf, H. Spencer. 2011. "Regulatory Impact Analyses of Environmental Justice Effects." Journal of Land Use and Environmental Law, forthcoming.

Banzhaf, H. Spencer, and Randall P. Walsh. 2008. "Do People Vote with their Feet? An Empirical Test of Tiebout's Mechanism." American Economic Review 98: 843-63.

Banzhaf, H. Spencer, and Randall P. Walsh. 2010. "Segregation and Tiebout Sorting: Investigating the Link between Investments in Public Goods and Neighborhood Tipping." NBER Working Paper 16057. http://ideas.repec.org/p/nbr/nberwo/16057.html. 
Becker, Gary S. 1957. The Economics of Discrimination. Chicago: University of Chicago Press.

Becker, Gary S. 1983. "A Theory of Competition among Pressure Groups for Political Influence." Quarterly Journal of Economics 98: 371-400.

Becker, Gary S., and Kevin M. Murphy. 2000. Social Economics: Market Behavior in a Social Environment, Chapter 5. Cambridge, MA: Belknap Press.

Been, Vicki. 1993. "What's Fairness Got to Do with It? Environmental Justice and the Siting of Locally Undesirable Land uses." Cornell Law Review 78: 1001-85.

Been, Vicki. 1994. "Locally Undesirable Land Uses in Minority Neighborhoods: Disproportionate Siting or Market Dynamics?" Yale Law Journal 103: 1383-1422.

Been, Vicki. 1997. "Coming to the Nuisance or Going to the Barrios? A Longitudinal Analysis of Environmental Justice Claims." With Francis Gupta. Ecology Law Quarterly 34: 3-56. Binder, Denis, Colin Crawford, Eileen Gauna, M. Casey Jarman, Alice Kaswan, Bradford C. Mank, Catherine A. O'Neill, Clifford Rechtschaffen, and Robert R.M. Verchick. 2001. "A Survey of Federal Agency Response to President Clinton's Executive Order No. 12898 on Environmental Justice." Environmental Law Reporter 31: 11133-50.

Blais, Lynne E. 1996. "Environmental Racism Reconsidered." North Carolina Law Review 75: $75-151$.

Boer, J. Tom, Manual Pastor, Jr., James L. Sadd, and Lori D. Snyder. 1997. "Is There Environmental Racism? The Demographics of Hazardous Waste in Los Angeles County." Social Science Quarterly 78:793-810.

Bowen, William. 2002. "An Analytical Review of Environmental Justice Research: What Do We really Know?" Environmental Management 29: 3-15.

Brooks and Sethi. 1997. "The Distribution of Pollution: Community Characteristics and 
Exposure to Air Toxics." Journal of Environmental Economics and Management 32: $233-50$.

Brueckner, Jan K., and Stuart S. Rosenthal. 2009. "Gentrification and Neighborhood Housing Cycles: Will America's Future Downtowns be Rich?" Review of Economics and Statistics 91: 725-43.

Brulle, Robert J., and David N. Pellow. 2006. "Environmental Justice: Human Health and Environmental Inequalities." Annual Review of Public Health 27: 103-24.

Bryant, Bunyan. 1995. "Introduction." In Environmental Justice: Issues, Policies, and Solutions, ed. by Bunyan Bryant. Washington, DC: Island Press.

Bullard, Robert D. 1990. Dumping in Dixie: Race, Class, and Environmental Quality. Boulder, CO: Westview Press.

Card, David, Alexandre Mas, and Jesse Rothstein. 2008. "Tipping and the Dynamics of Segregation." Quarterly Journal of Economics 123: 177-218.

Coase, Ronald H. 1960. "The Problem of Social Cost." Journal of Law and Economics 3: 1-44.

Cole, Luke W., and Sheila R. Foster. 2001. From the Ground Up: Environmental Racism and the Rise of the Environmental Justice Movement. New York: New York University Press.

Cutler, David M., Edward L. Glaeser, and Jacob L. Vigdor. 1999. "The Rise and Decline of the American Ghetto." Journal of Political Economy 107(3): 455-506.

Farley, Reynolds, Howard Schuman, Suzanne Bianchi, Diane Colasanto, and Shirley Hatchett. 1978. "Chocolate City, Vanilla Suburbs: Will the Trend toward Racially Separate Communities Continue?" Social Science Research 7: 319-344.

Farley, Reynolds, and Maria Krysan. 2002. "The Residential Preferences of Blacks: Do They Explain Persistent Segregation?" Social Forces, 80: 937-80. 
Fisher, Joshua B., Maggi Kelly, and Jeff Romm. 2006. "Scales of environmental justice: Combining GIS and spatial analysis for air toxics in West Oakland, California." Health and Place 12: 701-14.

Ford, Richard Thompson. 1994. "The Boundaries of Race: Political Geography in Legal Analysis." Harvard Law Review 107: 1841-1921.

Foster, Sheila. 1998. "Justice from the Ground up: Distributive Inequities, Grassroots Resistance, and the Transformative Politics of the Environmental Justice Movement." California Law Review 86: 775-841.

Goldman, Benjamin A. and Laura Fitton. 1994. Toxic Wastes and Race Revisited: An Update of the 1987 Report on the Racial and Socioeconomic Characteristics of Communities with Hazardous Waste Sites. Washington, DC: The Center for Policy Alternatives, National Association for the Advancement of Colored People, United Church of Christ.

Hamilton, James T. 1993. "Politics and Social Costs: Estimating the Impact of Collective Action on Hazardous Waste Facilities." Rand Journal of Economics 24: 101-125.

Hamilton, James T. 1995. "Testing for Environmental Racism: Prejudice, Profits, Political Power?" Journal of Policy Analysis and Management 14: 107-32.

Hamilton, James T., and W. Kip Viscusi. 1999. Calculating Risks: The Spatial and Political Dimensions of Hazardous Waste Policy. MIT Press.

Hanson, Andrew, and Zachary Hawley. 2011. "Do Landlords Discriminate in the Rental Housing Market? Evidence from an Internet Field Experiment in U.S. Cities."Journal of Urban Economics, forthcoming.

Hersch, Robert. 1995. "Race and Industrial Hazards: An Historical Geography of the Pittsburgh Region, 1900-1990. Resources for the Future Discussion Paper 95-18. 
Jenkins, Robin R., Kelly B. Maguire, and Cynthia L. Morgan. 2004. "Host Community Compensation and Municipal Solid Waste Landfills." Land Economics 80: 513-28.

Kriesel, Warren, Terrence J. Centner, and Andrew G. Keeler. 1996. "Neighborhood Exposure to Toxic Releases: Are there Racial Inequities?" Growth and Change 27: 479-99.

Lazarus, Richard J. 2000. "'Environmental Racism! That's What it is."' University of Illinois Law Review 2000: 255-74.

Maantay, Juliana. 2007. "Asthma and Air Pollution in the Bronx: Methodological and Data Considerations in Using GIS for Environmental Justice and Health Research." Health and Place 13: 32-56.

McCubbins, Matthew D., and Thomas Schwartz. 1984. "Congressional Oversight Overlooked: Police Patrols versus Fire Alarms." American Journal of Political Science 28: 165-79. McGuire, Martin. 1974. “Group Segregation and Optimal Jurisdictions.” Journal of Political Economy 82: 112-32.

Mohai, Paul, and Robin Saha. 2006. "Reassessing Racial and Socioeconomic Disparities in Environmental Justice Research." Demography 43: 383-99.

Morello-Frosch, Rachel, Manuel Pastor, and James Sadd. 2001. "Environmental Justice and Southern California's 'Riskscape': The Distribution of Air Toxics Exposures and Health Risks Among Diverse Communities." Urban Affairs Review 36: 551-578.

National Environmental Justice Advisory Council (NEJAC). 2006. Unintended Impacts of Redevelopment and Revitalization Efforts in Five Environmental Justice Communities. Final Report. http://www.epa.gov/compliance/ej/resources/publications/nejac/redev-revitalrecomm-9-27-06.pdf.

Noonan, Douglas S. 2008. "Evidence of Environmental Justice: A Critical Perspective on the 
Practice of EJ Research and Lessons for Policy Design." Social Science Quarterly 89: 1153-74.

Noonan, Douglas S., Rama Mohana R. Turaga, and Brett M. Baden. 2009. "Superfund, Hedonics, and the Scale of Environmental Justice." Environmental Management 44: 909-20.

Pastor, Manuel. 2002. "Environmental Justice: Reflections from the United States." Conference Paper No. 1, Political Economy Research Institute, University of Massachusetts at Amherst.

Pastor, Manuel, Jim Sadd, and John Hipp. 2001. "Which came first? Toxic facilities, minority move-in, and environmental justice." Journal of Urban Affairs 23: 1-21.

Pastor, Manuel, James Sadd, and Rachel Morello-Frosch. 2004. "Waiting to Inhale: The Demographics of Toxic Air Release Facilities in 21st-Century California." Social Science Quarterly 85: 420-40.

Pastor, Manuel, James Sadd, and Rachel Morello-Frosch. 2007. "Still toxic after all these years: Air quality and environmental justice in the San Francisco Bay Area." Center for Justice, Tolerance, and Community. University of California, Santa Cruz. http://cjtc.ucsc.edu/docs/bay_final.pdf.

Pulido, Laura. 2000. "Rethinking Environmental Racism: White Privilege and Urban Development in Southern California." Annals of the Association of American Geographers 90: $12-40$.

Ringquist, Evan J. 1997. "Equity and the Distribution of Environmental Risk: The Case of TRI Facilities." Social Science Quarterly 78: 811-29.

Ringquist, Evan J. 2003. "Environmental Justice: Normative Concerns, Empirical Evidence, and Government Action." In Environmental Policy: New Directions for the Twenty-First 
Century, ed. by Norman J. Vig and Michael E. Kraft. Washington, DC: CQ Press.

Ringquist, Evan J. 2005. "Assessing Evidence of Environmental Inequities: A Meta-Analysis." Journal of Policy Analysis and Management 24(2): 223-247.

Rosenthal, Stuart S. 2008. "Old Homes, Externalities, and Poor Neighborhoods: A Model of Urban Decline and Renewal." Journal of Urban Economics 63: 816-40.

Sadd, James L., Manuel Jr. Pastor, J. Thomas Boer, and Lori D. Snyder. 1999. "'Every Breath You Take...': The Demographics of Toxic Air Releases in Southern California." Economic Development Quarterly 13:107-23.

Saha, Robin, and Paul Mohai. 2005. "Historical Context and Hazardous Waste Facility Siting: Understanding Temporal Patterns in Michigan." Social Problems 52:618-48.

Schelling, Thomas C. 1971. "Dynamic Models of Segregation." Journal of Mathematical Sociology 1: $143-86$.

Schelling, Thomas C. 1972. "A Process of Residential Segregation: Neighborhood Tipping." Racial Discrimination in Economic Life, edited by A. Pascal. Lexington, MA.: Lexington, 1972.

Sieg, Holger, V. Kerry Smith, H. Spencer Banzhaf, and Randy Walsh. 2004. "Estimating the General Equilibrium Benefits of Large Changes in Spatially Delineated Public Goods." International Economic Review 45(4): 1047-77.

Tiebout, Charles. 1956. " A Pure Theory of Local Expenditures." Journal of Political Economy 64: 416-24.

Turner, Margery Austin, Fred Freiberg, Erin Godfrey, Carla Herbig, Diane K. Levy, Robin R. Smith. 2002. All Other Things Being Equal: A Paired Testing Study of Mortgage Lending Institutions. Urban Institute report prepared for the U.S. Department of Housing and 
Urban Development, Office of Fair Housing and Equal Opportunity. http://www.urban.org/UploadedPDF/1000504_All_Other_Things_Being_Equal.pdf.

United Church of Christ. 1987. Toxic Wastes and Race in the United States. Report of the Commission for Racial Justice.

United Church of Chirst. 2007. Toxic Wastes and Race at Twenty: 1987-2007. http://www.ucc.org/assets/pdfs/toxic20.pdf.

United States Environmental Protection Agency (US EPA). 2010. http://www.epa.gov/environmentaljustice/

United States General Accounting Office (GAO). 1983. Siting Hazardous Waste Landfills and their Correlation with Racial Status of Surrounding Communities.

Videras, Julio, and Christopher Bordoni. 2006. "Ethnic heterogeneity and the enforcement of environmental regulation." Review of Social Economy 64: 539-62.

Vigdor, Jacob. 2004. "Community Composition and Collective Action: Analyzing Initial Mail Response to the 2000 Census." Review of Economics and Statistics 86: 303-12.

Walsh, Randall P. 2007. "Endogenous Open Space Amenities in a Locational Equilibrium." Journal of Urban Economics 61: 319-44.

Wolverton, A. 2009. "Effects of Socio-Economic and Input-Related Factors on Polluting Plants' Location Decisions." Berkeley Electronic Journal of Economic Analysis and Policy, Advances 1. 


\section{Notes}

${ }^{1}$ On the location of landfills and hazardous waste facilities, see US GAO (1983), United Church of Christ (1987, 2007), Goldman and Fitton (1994), Baden and Coursey (2002), Been (1997), Boer et al. (1997), Pastor, Sadd, and Hipp (2001), Saha and Mohai (2005), Mohai and Saha (2006), and Maantay (2007). On the presence of large polluters, see Hersh (1995), Ringquist (1997), Sadd et al. (1999), Fisher, Kelly, and Romm (2006), and Banzhaf, Sidon, and Walsh (this volume). On the emissions of air pollutants, see Kriesel, Centner, and Keeler (1996), Brooks and Sethi (1997), Rinquist (1997), Arora and Cason (1999), and Pastor, Sadd, and Morello-Frosch (2004, 2007); and on estimated air pollution concentrations, see Morello-Frosch, Pastor, and Sadd (2001), Ash and Fetter (2004), Fisher, Kelly, and Romm (2006), Pastor, Sadd, and Morello-Frosch (2007), and Depro and Timmins (this volume).

Bullard (1990) is the classic book-length introduction to the entire literature. For more recent reviews and discussion, see Cole and Foster (2001), Bowen (2002), Pastor (2002), Ringquist (2003), Brulle and Pellow (2006), and Noonan (2008). See Ringquist (2005) for a meta-analysis.

${ }^{2}$ An exception is the sensitivity of the results to spatial scale, with evidence of the correlation between pollution and demographics stronger at smaller, more disaggregate scales. See Mohai and Saha (2006), Baden, Noonan, and Turaga (2007), and Noonan, Turaga, and Baden (2009).

${ }^{3}$ In addition to impeding new permits, sometimes these activities include bargaining for compensation (Jenkins et al. 2004).

${ }^{4}$ See Lazarus 2000, Binder et al. 2001, and the United Church of Christ (2007) on the tangible successes of the environmental justice movement.

${ }^{5}$ We particularly thank Joseph Aldy, Vicki Been, Robert Deacon, and Jason Johnston for their very valuable and constructive comments.

${ }^{6}$ Alchian and Demsetz (1973) point out that ownership is equivalent to the rights to use a resource. Because there may be many uses, property rights are almost infinitely divisible. The owner of "the right" to use of a parcel of land, for example, may differ for the right to occupancy, the mineral rights, water rights, right-of-way, and so forth. In the same way, even if common law does not give communities a right to be free from pollution, statutory or administrative law may give communities the right to contest the permitting process for citing a facility nearby. It is this 
right which may give rise to Coasian bargaining, even without plain and unambiguous property rights over every aspect of the resources at stake. Indeed, such actions lie at the heart of the environmental justice movement's strategy today.

${ }^{7}$ Loosely, procedural justice in this context refers to the fairness of the processes that determine the ultimate spatial distribution of pollution. EPA is, naturally, focused on the fairness of federal rule-making, but others would emphasize other processes, including business planning, political negotiation, and even the market itself. Distributive justice refers to the fairness or equity of the ultimate distribution of pollution itself. So long as there is a correlation between pollution and demographics, there is at least a prima facie case for distributive injustice, however it arises. On the inter-relationship between procedural and distributive justice issues in the environmental context, see Foster (1998) and Banzhaf (2011).

${ }^{8}$ At one time, environmental justice activists sought a remedy in Title VI of the Civil Rights Act, under rules for agencies using federal money. These rules required only proof of discriminatory effect rather than proof of intent. However, the Supreme Court ruled in 2001 in Alexander $v$. Sandoval (532 U.S. 275) that there was no private right of action to enforce such regulations. 9 The tide against explicit discrimination began to turn with the Supreme Court's decision in Shelley v. Kraemer (1948), striking down restrictive covenants, and with passage of the Fair Housing Act of 1968. While the existence of overt discrimination in housing markets did not immediately disappear, its importance has steadily declined. Nevertheless, discriminatory practices are believed to continue to play a role in the locational opportunities of different racial groups (see Turner et al. 2002, Hanson and Hawley 2011). 